\title{
A Nonribosomal Peptide Synthetase Gene (mgoA) of Pseudomonas syringae pv. syringae Is Involved in Mangotoxin Biosynthesis and Is Required for Full Virulence
}

\author{
Eva Arrebola, Francisco M. Cazorla, Diego Romero, Alejandro Pérez-García, and Antonio de Vicente
}

Departamento de Microbiología, Facultad de Ciencias, Universidad de Málaga, Málaga, Spain

Submitted 4 September 2006. Accepted 19 December 2006.

\begin{abstract}
Pseudomonas syringae pv. syringae, which causes the bacterial apical necrosis of mango, produces the antimetabolite mangotoxin. We report here the cloning, sequencing, and identity analysis of a chromosomal region of $11.1 \mathrm{~kb}$ from strain $P$. syringae pv. syringae UMAF0158, which is involved in mangotoxin biosynthesis. This chromosomal region contains six complete open reading frames (ORFs), including a large gene (ORF5) with a modular architecture characteristic of nonribosomal peptide synthetases (NRPS) named $\operatorname{mgoA}$. A Tn5 mutant disrupted in $\operatorname{mgoA}$ was defective in mangotoxin production, revealing the involvement of the putative NRPS gene in the biosynthesis of mangotoxin. This derivative strain impaired in mangotoxin production also showed a reduction in virulence as measured by necrotic symptoms on tomato leaflets. Mangotoxin production and virulence were restored fully in the NRPS mutant by complementation with plasmid pCG2-6, which contains an 11,103-bp chromosomal region cloned from the wildtype strain $P$. syringae pv. syringae UMAF0158 that includes the putative NPRS gene (mgoA). The results demonstrate that $m g o A$ has a role in the virulence of $P$. syringae pv. syringae. The involvement of an NRPS in the production of an antimetabolite toxin from $P$. syringae inhibiting ornithine acetyltransferase activity is proposed.
\end{abstract}

Additional keywords: Mangifera indica.

Pseudomonas syringae is an epiphytic plant-pathogenic bacterium that infects a large variety of plants and produces a wide spectrum of phytotoxic compounds (Bender et al. 1999). Among them the best characterized are the lipodepsipeptidic toxins, syringomycins and syringopeptins, and the antimetabolite toxins, phaseolotoxin and tabtoxin (Bender et al. 1999). In general, the phytotoxins produced by $P$. syringae pathovars are non-host specific (Mitchell 1984). Although not essential for pathogenicity, they generally act as virulence factors and, hence, are involved in disease symptom production in many plants (Bender et al. 1999; Durbin 1991; Gross 1991). The genes involved in the production of these toxins mainly are

Corresponding author: Antonio de Vicente; Fax: 34-952131889; E-mail: adevicente@uma.es

Nucleotide sequence data reported are available in the GenBank database under accession numbers DQ532433 to DQ532440 for the interrupted genes in the eight mutants described, DQ532441 for the genomic sequence in pCG2-6, and DQ532442 for the $m g o A$ gene (ORF5). clustered in the bacterial chromosome and, in certain cases, as for lipodepsipeptides, they include nonribosomal peptide synthetase (NRPS) systems (Bender et al. 1999; Scholz-Schroeder et al. 2003).

Antimetabolite toxins are produced by several pathovars of $P$. syringae and include metabolites of diverse chemical structure that are effective at very low concentrations (Mitchell 1991). Two of the better known of these phytotoxins are tabtoxin and phaseolotoxin. Tabtoxin is a monocyclic $\beta$-lactam with chlorosis-inducing activity (Mitchell 1991) that irreversibly inhibits glutamine synthetase (Thomas et al. 1983). The biosynthesis of tabtoxin is not completely elucidated. However, a proposed biosynthetic model of tabtoxin formation resembles that of lysine (Bender et al. 1999). Other authors have suggested that tabtoxin biosynthesis branches off from the lysine biosynthetic pathway before the formation of diaminopimelate (Roth et al. 1990; Unkefer et al. 1987). Phaseolotoxin is a sulfodiaminophosphinyl moiety linked to a tripeptide consisting of ornithine, alanine, and homoarginine (Bender et al. 1999), which produces chlorosis by inhibition of ornithine carbamoyl transferase (Patil et al. 1972) and ornithine decarboxylase (Bachmann et al. 1998). The biosynthetic precursors for this toxin have not been identified (Märkisch and Reuter 1990). It has been demonstrated that the homoarginine and ornithine residues of phaseolotoxin are synthesized by a transamidination reaction from arginine and lysine (Hernández-Guzmán and Álvarez-Morales 2001; Zhang and Patil 1997). A nonribosomal thiotemplate mechanism may be required for biosynthesis of phaseolotoxin, but it has yet to be demonstrated (Bender et al. 1999).

Our group reported $P$. syringae pv. syringae as the agent for bacterial apical necrosis of mango (Mangifera indica L.) (Cazorla et al. 1998). In addition, $P$. syringae pv. syringae causes disease in a large variety of plants (Hirano and Upper 1990). P. syringae pv. syringae strains isolated from mango, as well as those isolated from other plants hosts such as tomato, have been demonstrated to produce a novel antimetabolite toxin named mangotoxin in addition to lipodepsipeptides (Arrebola et al. 2003; Cazorla et al. 2003). Mangotoxin inhibits ornithine acetyl transferase, a key enzyme in the biosynthetic pathway of ornithine and arginine. Although the molecular structure of mangotoxin remains unknown, a preliminary biochemical characterization showed that the toxin has features of a small oligopeptide, resembling those of other antimetabolite toxins (Arrebola et al. 2003).

Syringomycins are a representative of the cyclic lipodepsinonapeptide class of $P$. syringae phytotoxins, which are composed of a polar peptide head and a hydrophobic 3-hydroxy 
fatty acid tail (Segre et al. 1989). This family of toxins induces necrosis in plant tissues, and early studies of its mode of action established that the plasma membrane of host cells is the primary target (Backman and DeVay 1971). These toxins are synthesized via an NRPS (Grgurina and Benincasa 1994; Lu et al. 2002; Raaijmakers et al. 2006; Scholz-Schroeder et al. 2001), which catalyzes the activation and addition of amino acids into the peptide chain (Konz and Marahiel 1999; Marahiel et al. 1997).

NRPS consists of an arrangement of modules with at least three different types of domains: the adenylation domain (A) that activates an amino acid monomer; a thiolation domain (T), also named peptidyl carrier protein (PCP), that tethers the growing peptide; and a condensation domain $(\mathrm{C})$ that catalyses the formation of the peptidic bound between the activated amino acid and the growing peptide (Finking and Marahiel 2004). In addition to the basic subset of core domains, each NRPS could include a domain responsible for the initiation of chain assembly and a chain termination or reductase (R) domain (Finking and Marahiel 2004; Marahiel 1997; Schwarzer et al. 2003). Thus, NRPS systems are used simultaneously as templates, because the amino acid to be incorporated is determined by the module, and as biosynthetic machinery, because the module harbors all necessary catalytic functions (Finking and Marahiel 2004). In bacteria, NRPS modules usually are distributed over several genes organized in an operon. However, in some cases, an NRPS with only one single module is able to produce small active oligopeptides (Finking and Marahiel 2004). The syringopeptin synthetase $\mathrm{C}$ gene (sypC), involved in syringomycin biosynthesis currently is the largest bacterial NRPS known, comprising a total of 12 modules (ScholzSchroeder et al. 2003). In the genus Pseudomonas, many bacterial peptides, including secondary metabolites, are synthesized by NRPS systems (Konz and Marahiel 1999).

The wild-type strain $P$. syringae pv. syringae UMAF0158 produces the antimetabolite mangotoxin. In this work, we describe the cloning and DNA sequencing of a putative NRPS gene, which we named $m g o A$, present in the chromosome of this strain, and report on the role of $m g o A$ in mangotoxin biosynthesis and virulence of $P$. syringae pv. syringae.

\section{RESULTS}

Isolation of mangotoxin defective mutants of $P$. syringae pv. syringae UMAF0158.

To detect putative genes involved in mangotoxin production, a mini Tn5 mutagenesis was carried out. Derivative mutants from strain $P$. syringae pv. syringae UMAF0158 were obtained by conjugation experiments using as donor the Escherichia coli

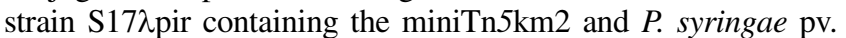
syringae UMAF0158 as a recipient. From a collection of 2,592 exconjungants, 18 derivative strains defective in mangotoxin production were isolated by the $E$. coli growth inhibition assay, and 8 of them were selected based on their lipodepsipeptidic toxin production and growth on minimal medium for more detailed analysis (Table 1). Five mutants displayed an increased production of lipodepsipeptidic toxin (Table 2). Also, four derivative $P$. syringae pv. syringae strains displayed altered growth on minimal medium, showing lower bacterial counts after the fourth day of growth when compared with the wild-type strain $P$. syringae pv. syringae UMAF0158 (Table 2). Only three derivative strains impaired in mangotoxin production ( $P$. syringae pv.

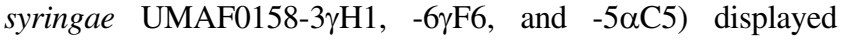
growth characteristics and production of lipodepsipeptidic toxins similar to the wild-type strain (Table 2).

Sequencing of the flanking DNA of the miniTn $5 \mathrm{~km} 2$ insertions showed that five of the derivative mutants were located in DNA with a high similarity to the global regulatory genes gac A and $g a c \mathrm{~S}$, or to genes encoding hypothetical proteins of $P$. syringae pv. syringae $\mathrm{B} 728 \mathrm{a}$ and $P$. syringae $\mathrm{pv}$. tomato DC3000 (Table 2). The insertion on the mutants $P$. syringae pv. syringae UMAF0158-4ßA2 and $P$. syringae pv. syringae UMAF0158-5 $\alpha \mathrm{C} 5$ was located in regions that did not show identity with sequenced genomes from $P$. syringae strains, but they showed partial identity with a protein involved in the outer membrane biosynthesis of Burkholderia dolosa AUO158 and a carboxylase of B. pseudomallei 668, respectively. Finally, in mutant $P$. syringae pv. syringae

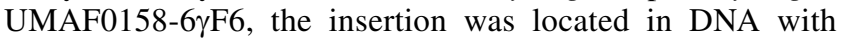
high similarity to an NRPS gene from $P$. syringae pv. syringae B728a (Psyr 5011, 95\%), P. syringae pv. tomato DC3000

Table 1. Bacterial strains and vectors used in this study

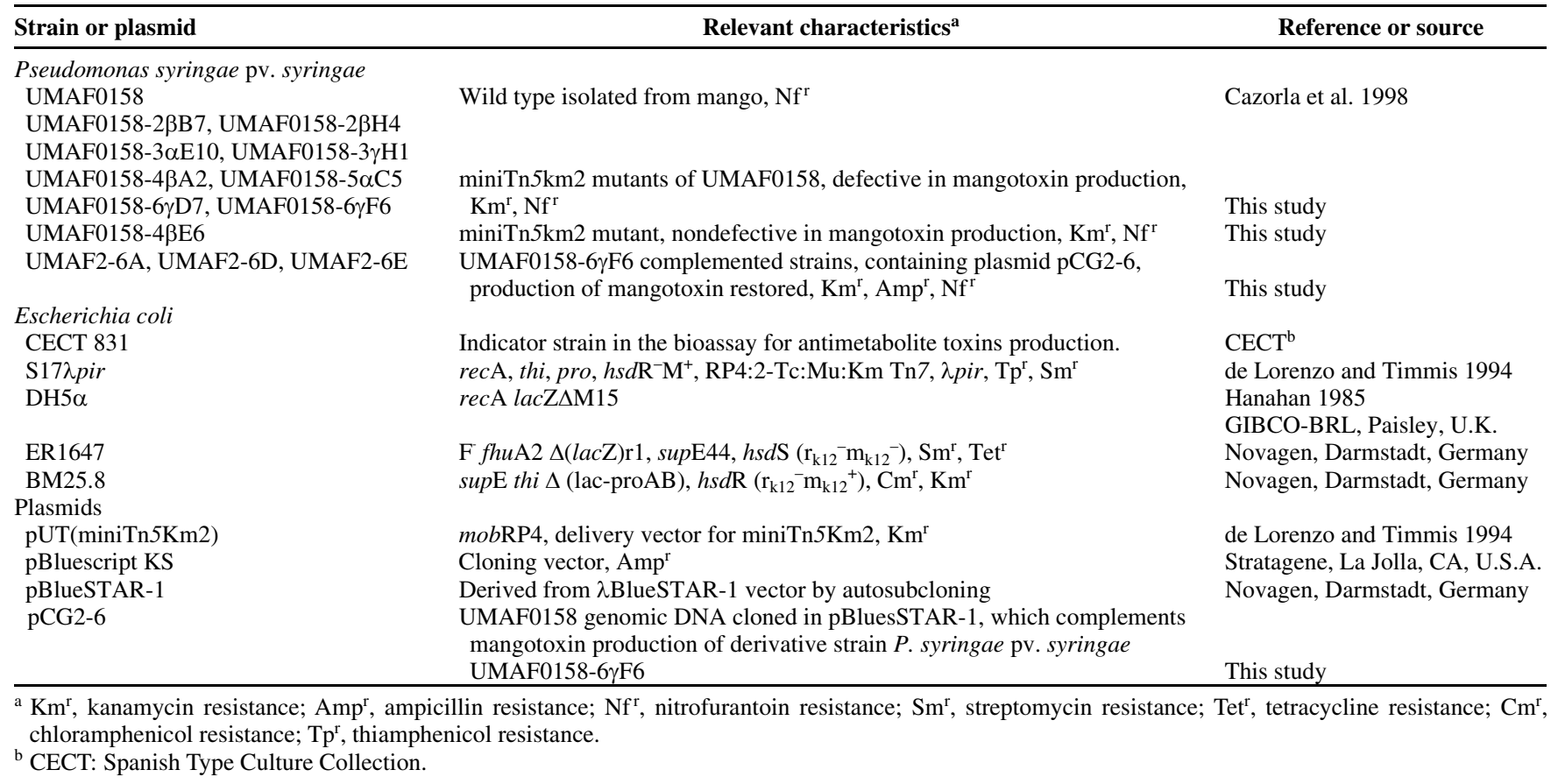

Vol. 20, No. 5, 2007 / 501 
(PSPTO 5457, 88\%), and P. syringae pv. phaseolicola 1448A (PSPPH 5090, 88\%) (Table 2).

Mutant $P$. syringae pv. syringae UMAF0158-6 $\gamma \mathrm{F} 6$ was selected for further experiments because it produced levels of lipodepsipeptidic toxins and showed growth characteristics similar to those of the wild-type strain $P$. syringae pv. syringae UMAF0158, and because of the high similarity of the disrupted gene to those encoding for NRPS involved in toxin production in other microorganisms.

\section{Analysis of a chromosomal region encoding for an NRPS.}

In order to search for the gene or genes involved in mangotoxin production, a phage library from $P$. syringae pv. syringae UMAF0158 DNA was constructed and screened using as a probe the right flank of the disrupted gene in the defective mutant $P$. syringae pv. syringae UMAF0158-6 $\gamma \mathrm{F} 6$. Of 3,000 plaques screened, eight phagemids hybridized to the probe and, hence, were selected for further analysis. Several plasmids with different sizes were isolated; then, the biggest in size $(13.2 \mathrm{~kb})$ of them (pCG2-6, Table 1) was selected and electroporated into the mangotoxin-defective mutant UMAF0158-6 $\gamma \mathrm{F} 6$, to confirm the role of this genetic trait in mangotoxin production.

Three different complemented $P$. syringae pv. syringae strains (UMAF2-6A, UMAF2-6D, and UMAF2-6E) obtained from three independent experiments of complementation had restored mangotoxin production, which was demonstrated by both ornithine acetyltransferase (OAT) activity assay and $E$. coli growth inhibition bioassay (Table 3), in comparison with the wild-type strain and the mangotoxin-defective mutant $P$.

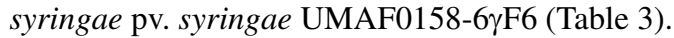

By Southern blot analysis on the complemented strains, only one hybridization signal of the DNA fragment from $P$. syringae pv. syringae UMAF0158 cloned in pCG2-6 was associated with chromosomal but not to plasmid DNA, revealing integration of the plasmid sequence in the chromosome of the derivative strain. Sequence analysis of the plasmid pCG2-6, which restored mangotoxin production in the derivative strain UMAF0158$6 \gamma$ F6, showed a DNA insert of 11,103 bp. Six complete open reading frames (ORFs) were defined within the 11.1-kb fragment (Fig. 1), designated as ORF1 to ORF6, followed by genes encoding from the rRNA $5 \mathrm{~S}$ and $23 \mathrm{~S}$. Also, an incomplete ORF (ORF -1, $472 \mathrm{bp}$ ) was observed at the beginning of the DNA fragment (Fig. 1). Analysis of deduced amino acid sequences of these ORFs indicated that all ORFs had a high similarity to genes sequenced in strains $P$. syringae pv. syringae $\mathrm{B} 728 \mathrm{a}, P$. syringae pv. tomato $\mathrm{DC} 3000$, and $P$. syringae pv. phaseolicola 1448A, and were arranged in the same order (Fig. 1). The analysis of predicted sites for putative promoters resulted in the presence of three sites, upstream of ORF2 $(P=0.87)$, ORF3 $(P=$ $0.95)$, and 5S rDNA $(P=0.87)$ (Fig. 1). Similar predicted sites for putative promoters were found in the homologous sequence of $P$. syringae pv. syringae $\mathrm{B} 728 \mathrm{a}$ and $P$. syringae pv. tomato DC3000, allocated upstream of the correspondent genes homologous to ORF2, ORF3, and 5S rDNA.

The miniTn $5 \mathrm{~km} 2$ insertion in the mutant $P$. syringae pv. syringae UMAF0158-6 $\gamma \mathrm{F} 6$ was located in the nucleotide 3,014 of the ORF5 sequence $(3,447 \mathrm{bp})$. This ORF5 was named gene mgoA. A detailed analysis of the 1,148 amino acids from the deduced product of the mgoA gene in comparison with other peptide synthetases determined that it contains an amino acid activation module (Marahiel et al. 1997) composed of conserved motifs for aminoacyl adenylation, a peptidyl carrier protein region with a thiolation domain and a condensation domain (Stein and Vater 1996) (Fig. 2). The aminoacyl adenylation domains encompass 451 amino acids, containing nine conserved core

Table 3. Inhibition of Escherichia coli growth and specific inhibition of ornithine N-acetyl-transferase (OAT) activity by cell-free culture filtrates of mangotoxin-producing and nonproducing Pseudomonas syringae pv. syringae strains in liquid minimal medium (PMS)

\begin{tabular}{|c|c|c|}
\hline Culture filtrates of: & $\begin{array}{c}\text { Diameter of } \\
\text { inhibition zone }(\mathrm{mm})\end{array}$ & $\begin{array}{l}\text { OAT activity } \\
{\text { (nkat/gfw })^{\mathbf{a}}}^{\text {Onk }}\end{array}$ \\
\hline $\mathrm{PMS}^{\mathrm{b}}$ & Null & $6.75 \pm 1.36$ \\
\hline $\mathrm{PCMB}^{\mathrm{c}}$ & $\ldots$ & $1.21 \pm 0.81$ \\
\hline \multicolumn{3}{|c|}{ P. syringae pv. syringae } \\
\hline UMAF0158 & $22 \pm 1.8$ & $1.14 \pm 0.98$ \\
\hline UMAF0158-6 $\gamma \mathrm{F} 6$ & Null & $5.57 \pm 0.97$ \\
\hline UMAF0158-2ßH4 & Null & $5.80 \pm 1.08$ \\
\hline UMAF2-6A & $21 \pm 1.3$ & $1.45 \pm 1.08$ \\
\hline UMAF2-6D & $21 \pm 1.7$ & $1.45 \pm 0.95$ \\
\hline UMAF2-6E & $22 \pm 1.6$ & $1.14 \pm 0.77$ \\
\hline UMAF0158-4קE6 & $20 \pm 0.5$ & $1.69 \pm 1.15$ \\
\hline
\end{tabular}

${ }^{a}$ Average and standard deviation values obtained from five independent replicated experiments; nkat/gfw = nanokatals/g of fresh weight.

b Negative inhibition control

${ }^{\mathrm{c}} \mathrm{PCMB}=\mathrm{p}$-chloromercuribenzoic acid; specific inhibitor of OAT activity.

Table 2. Characterization of eight transposon mutants, derived from the wild-type strain of Pseudomonas syringae pv. syringae UMAF0158, impaired in mangotoxin production, and analysis of the flanking regions of the miniTn5Km2 insertion by comparison with the sequenced genome of $P$. syringae pv. syringae $\mathrm{B} 728 \mathrm{a}$

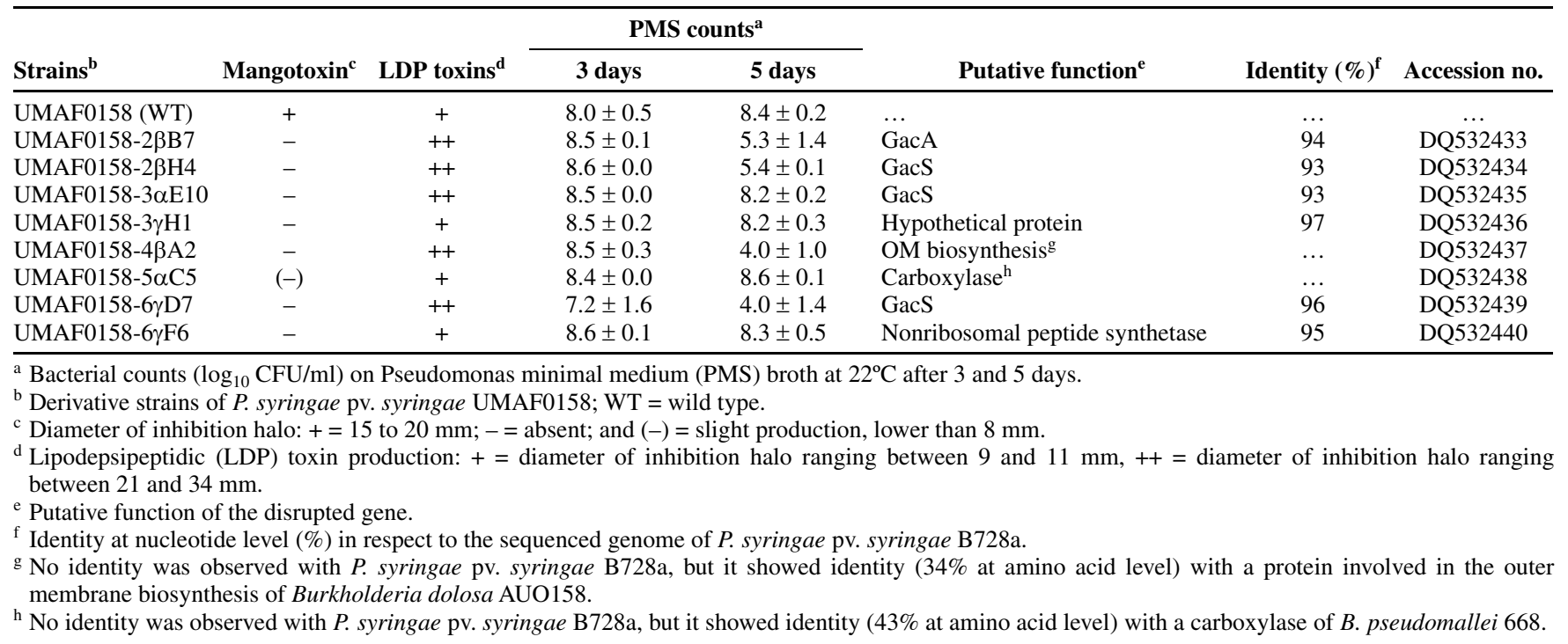


sequences (Fig. 2). Some of these conserved sequences include the conserved motif YTSGTTGXPKG (A3), the highly conserved YGPTE motif (A5), and the YRTGD motif (A7) (Fig. 2). The aminoacyl adenylation domains are followed by the thiolation domain of the PCP region (Fig. 2), which contains the conserved thioester binding motif LGGHS(T). The condensation domain (C) followed the thiolation domain, with QDY as the unique condensation core present on ORF5 protein, and it is highly conserved in the $P$. syringae strains analyzed (Fig. 2). The analysis of the substrate-binding region of the module by the NRPS predictor software showed that the residues around the substrate were FWYSFDSSIIDPFLMTGGDHNLYGPTEA TVLVTA, and they have a prediction of valine, leucine, isoleucine, 2-amino butiric acid, and isovaleric acid-like as the substrate amino acids (score 2.24560058905).

As expected, a carboxy-terminal reductase I domain of 189 amino acid residues was observed at the $\mathrm{C}$-terminal end of the deduced protein. This region contains three core sequences, including a binding domain to $\operatorname{NADP}(\mathrm{H})(\mathrm{R} 1)$ and the highly conserved RPG (R6) domain (Fig. 2). The different domains and motifs present in the putative NRPS encoded in $m g o \mathrm{~A}$ showed a high level of identity with those present in other bacteria (Fig. 2). Only minimal differences were observed among adenylation, condensation, and reductase domains present in different Pseudomonas spp.

\section{Symptom development and bacterial multiplication on tomato leaflets.}

To explore the involvement of the putative NRPS encoded by $m g o \mathrm{~A}$ (ORF5) in the virulence of $P$. syringae pv. syringae UMAF0158, we examined the development of disease symptoms and in planta multiplication of three bacterial strains $(P$. syringae pv. syringae UMAF0158-6 $\gamma \mathrm{F} 6$, the mangotoxin-defective mutant which contains a transposon insertion in ORF5; the mangotoxin-producing strain $P$. syringae pv. syringae UMAF0158; and the complemented strain $P$. syringae pv. syringae UMAF2-6A), using detached tomato leaflets. Leaflets were inoculated with a high bacterial dose by placing six $10-\mu \mathrm{l}$ droplets of a bacterial suspension (approximately $10^{8} \mathrm{CFU} / \mathrm{ml}$ ) on the principal lateral veins and piercing through them with an entomological pin. Analysis of bacterial growth in planta over 10 days revealed no significant differences between the strains assayed (Fig. 3).

The necrotic lesions produced on tomato leaflets by the inoculated strains were evaluated daily (Fig. 4). The strain $P$. syringae pv. syringae UMAF2-6A produced disease symptom levels similar to those observed in the wild-type strain $P$. syringae pv. syringae UMAF0158, but strain $P$. syringae pv. syringae UMAF0158-6 $\gamma \mathrm{F} 6$ caused clearly reduced symptoms when they were evaluated as the number of inoculation points where necrotic lesions were developed (Fig. 4). The mangotoxin-producing strains, wild-type and complemented, produced severe disease symptoms (necrotic areas with a diameter larger than 2 $\mathrm{mm}$ ) in more than $70 \%$ of the inoculation points within 6 days after inoculation, increasing every day, reaching more than $90 \%$ at the end of the assay (10 days); whereas the defective mutant $P$. syringae pv. syringae UMAF0158-6 $\gamma \mathrm{F} 6$ produced significant lesions in more than $50 \%$ of the inoculation points only after 10 days (Fig. 4A), and, in general, less severe symptoms were observed (Fig. 4B).

The virulence also was evaluated as a function of bacterial dose size (Table 4). The median effective dose that caused necrotic lesions in $50 \%$ of inoculations $\left(\mathrm{ED}_{50}\right)$ was estimated for the different strains from the straight line produced by adjusting the bacterial-inoculated dose ( $\log _{10}$-transformed) against the response data on a Weibull scale obtained from two independent assays. The $\mathrm{ED}_{50}$ of the mangotoxin-defective mutant

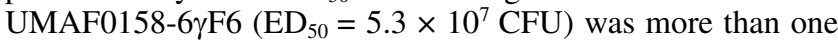
order of magnitude higher than those of the mangotoxin producer strains UMAF0158 $\left(1.8 \times 10^{6} \mathrm{CFU}\right)$ and UMAF2-6A $\left(8.0 \times 10^{5} \mathrm{CFU}\right)$ and the derivative strain UMAF0158-4 $\beta \mathrm{E} 6$ $\left(1.9 \times 10^{6} \mathrm{CFU}\right)$, which contains a miniTn $5 \mathrm{~km} 2$ insertion that did not alter mangotoxin production (Table 4).

\section{DISCUSSION}

The cloning and DNA sequence of a putative NRPS gene present in the chromosome of the mangotoxin-producing strain

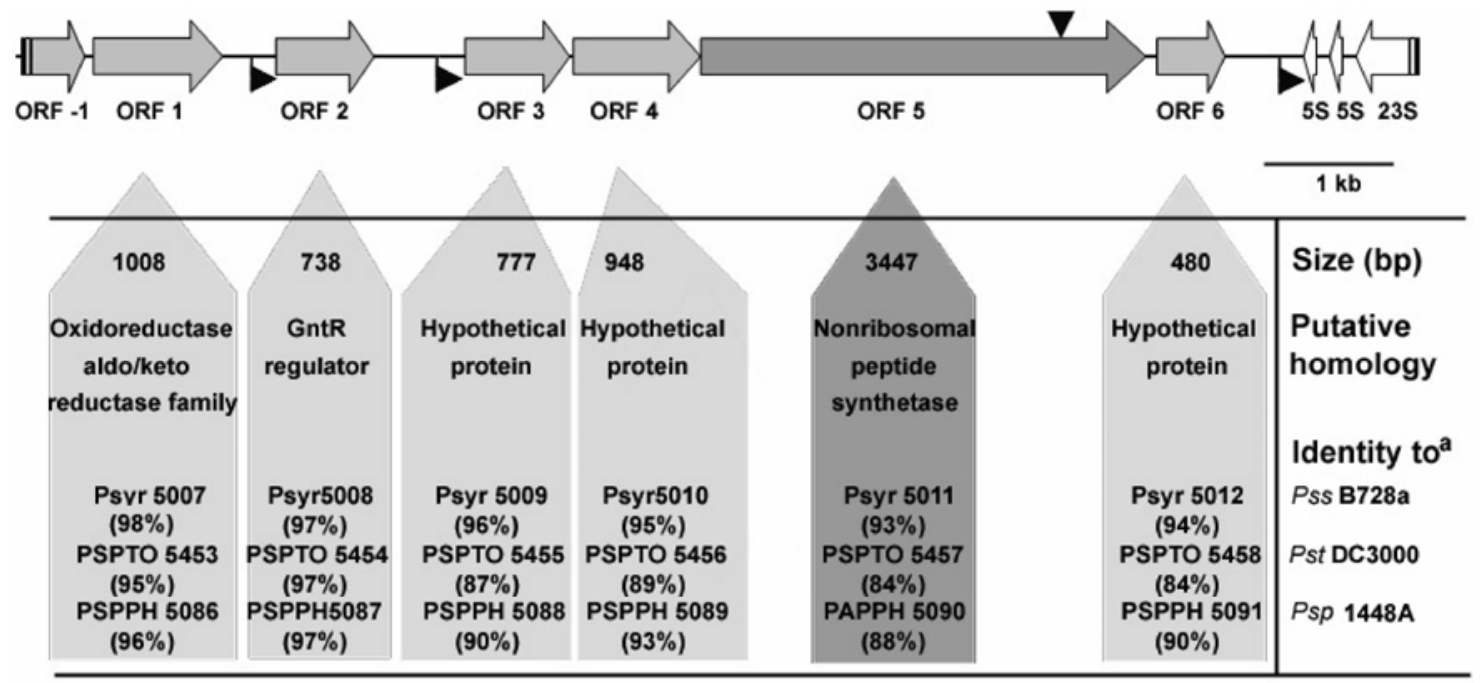

a) at amino acid level

Fig. 1. Arrangement of the open reading frames (ORFs) present in the chromosomal DNA fragment of 11,103 bp cloned into the plasmid pCG2-6. This plasmid was obtained from a phage library of the wild-type strain Pseudomonas syringae pv. syringae UMAF0158 and restores the mangotoxin production of the derivative mutant UMAF0158-6yF6. The line represents the sequenced genomic insert of P. syringae pv. syringae UMAF0158. Putative ORFs are indicated by thick arrows on the line. The insertion of the mini Tn5km2 in the derivative mutant UMAF0158-6 $\gamma$ F6, located in ORF5 is shown in the figure $(\boldsymbol{\nabla})$. Predicted sites for putative promoters were analyzed by the BPROM and NNPP 2.2. software, and are also marked ( $\boldsymbol{\nabla}$ ). Accession number of sequence from DNA fragment cloned into pCG2-6 is DQ532441. Size and putative homology of the different ORFs and identity to homologous genes sequenced in $P$. syringae pv. syringae B728a, P. syringae pv. tomato (Pst) DC3000, and P. syringae pv. phaseolicola (Psp) 1448A are indicated. 
$P$. syringae pv. syringae UMAF0158 have been performed, and the role of this NRPS gene in mangotoxin biosynthesis and virulence has reported.

Analysis of the disrupted genes in eight derivative strains impaired in mangotoxin production showed that, as observed with other compounds secreted by Pseudomonas spp. (Heeb and Hass 2001), the global regulator system $\mathrm{gacA} / \mathrm{gacS}$ is involved in the production of mangotoxin (Table 2). In this sense, it has been described recently that the salA gene, a member of the GacS/GacA system, is required for bacterial

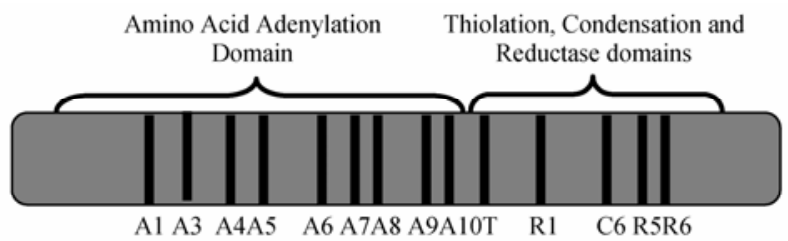

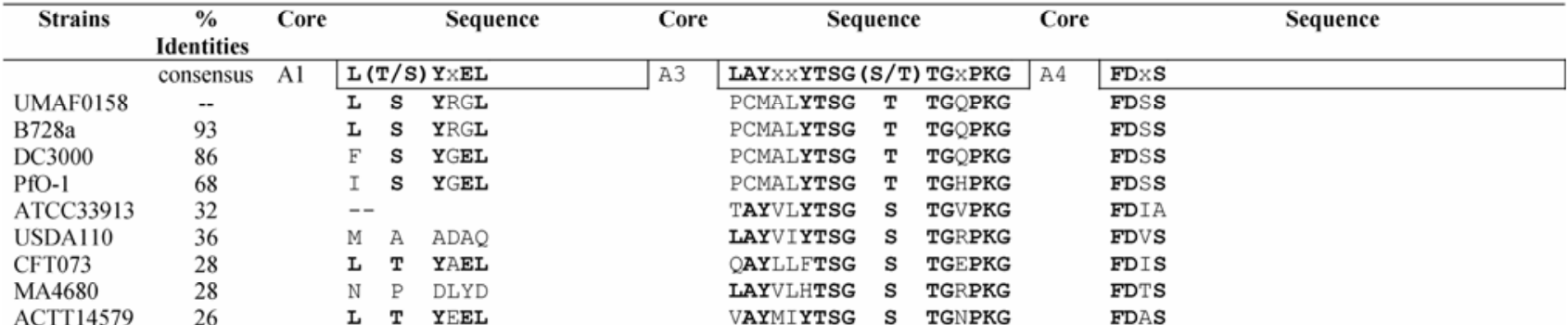

A5

\begin{tabular}{|l|}
\hline NXYGPTE \\
\hline NLYGPTE \\
NLYGPTE \\
NLYGPTE \\
NLYGPTE \\
QLYGPTE \\
NLYGPTE \\
NLYGPTE \\
NTYGPTE \\
NVYGPTE
\end{tabular}

A8

GRXDXQVKIRGXRIELGEIE

GRRDNQVKIRGFRVEPEEIE GRRDNQVKIRGFRVEPEEIE GRRDNQVKIRGFRVEPEEIE GRRDNQVKIRGFRVEPEEIE GRADGQLKIRGHRVEPAEIE GRNDDQVKIRGFRIEPGEIE GRKDSQIKLRGYRIELGEIE GRSDTEFKISGHRVHPAEVE HRKDDQVKIRGHRIELGEIQ

T

\begin{tabular}{|llll|}
\hline \multicolumn{3}{|l|}{ DXFFXXLGG (H/D) S (L/I) } \\
\hline MKLFN-LGG & H & S & I \\
DSFFN-LGG & H & S & I \\
ESFFN-LGG & H & S & I \\
ESFFN-LGG & H & S & I \\
DNFFE-LGG & D & S & L \\
DNFFE-LGG & H & S & I \\
MKLFN-LGG & H & S & L \\
DDVFD-LGG & H & S & L \\
DDFFT-IGG & H & S & L \\
\hline
\end{tabular}

R5

\begin{tabular}{ll}
\hline GYXXSKWXXE \\
\hline GYNLSKWVAE \\
GYNLSKWVAE \\
GYNLSKWVAE \\
GYNLSKWVGE \\
nP \\
SKDPERLAAQ \\
nP \\
GYQQSKWAAE \\
VYSNSKLQAE
\end{tabular}

\begin{tabular}{|lll|}
\hline \multicolumn{3}{|l|}{ GELXIXGXG (V/L) ARGYL } \\
\cline { 1 - 2 } GELYIVGPG & V & CLGYV \\
GELYIVGPG & V & CLGYV \\
GELYIVGPG & V & CLGYI \\
GELFIVGPG & V & CLGYL \\
GELYIGGAG & V & AKGYR \\
GELCIGGAG & V & ARGYL \\
GELYIAGDG & V & AQGYD \\
GELHLLGDN & L & AIGYR \\
GELYIDSVG & L & AKGYF
\end{tabular}

\begin{tabular}{|lll|}
\hline \multicolumn{1}{|l|}{$\mathrm{Y}(\mathrm{R} / \mathrm{K})$} & TGDL \\
\hline $\mathrm{Y}$ & $\mathrm{R}$ & TGDI \\
$\mathrm{Y}$ & $\mathrm{R}$ & TGDI \\
$\mathrm{Y}$ & $\mathrm{R}$ & TGDI \\
$\mathrm{Y}$ & $\mathrm{R}$ & SGDM \\
$\mathrm{Y}$ & $\mathrm{R}$ & TGDR \\
$\mathrm{Y}$ & $\mathrm{R}$ & TGDI \\
$\mathrm{Y}$ & $\mathrm{R}$ & TGDI \\
$\mathrm{Y}$ & $\mathrm{R}$ & TGDI \\
$\mathrm{Y}$ & $\mathrm{K}$ & TGDI \\
\hline
\end{tabular}

\section{A10 NGK (V/L) DR}

NGK $V$ DR NGK $\quad \mathrm{V} \quad \mathrm{DR}$ NGK $V$ DR NGK $\quad \mathrm{V} \quad \mathrm{DR}$ NGK L DR NGK L DR NGK I DR SGK I DR NKK $\quad$ I $\quad$ DR

\begin{tabular}{|c|c|c|c|}
\hline \multicolumn{4}{|c|}{$(\mathrm{H} / \mathrm{N}) \mathrm{QD}(\mathrm{Y} / \mathrm{V}) \mathrm{PFE}$} \\
\hline $\mathrm{V}$ & $Q D$ & $Y$ & PFE \\
\hline V & $Q D$ & $Y$ & ESL \\
\hline $\mathrm{V}$ & $\mathrm{QD}$ & $Y$ & ETL \\
\hline $\mathrm{V}$ & LD & $\mathbf{Y}$ & ESL \\
\hline \multicolumn{4}{|l|}{$\mathrm{np}$} \\
\hline $\mathrm{R}$ & GL & v & NLL \\
\hline \multicolumn{4}{|l|}{$\mathrm{np}$} \\
\hline M & $\mathrm{RE}$ & $Y$ & ATL \\
\hline F & $G D$ & v & $\mathrm{KQF}$ \\
\hline
\end{tabular}

\begin{tabular}{|lllllllll|}
\hline V $(\mathrm{L} / \mathrm{F})$ & $(\mathrm{L} / \mathrm{V})$ & $\mathrm{TG}(\mathrm{A} / \mathrm{V})$ & $(\mathrm{T} / \mathrm{N})$ & $\mathrm{G}$ & $(\mathrm{Y} / \mathrm{F})$ & LG \\
\hline V & I & V & TG & A & N & G & F & LG \\
V & I & V & TG & A & N & G & F & LG \\
V & I & V & TG & A & N & G & F & LG \\
V & I & V & TG & A & N & S & F & VG \\
np & & & & & & & & \\
G & L & S & PL & Q & D & G & I & LF \\
np & & & & & & & & \\
I & L & L & TG & A & T & G & F & VG \\
V & F & L & TG & A & T & G & Y & LG
\end{tabular}

\begin{tabular}{l|}
\hline RPG \\
\hline RPG \\
RPG \\
RPG \\
RPG \\
np \\
RTG \\
np \\
RLG \\
RAG
\end{tabular}

--
--
--
--
--
--
--
--
--
--

Fig. 2. Diagrammatic representation of $m g o A$ (open reading frame [ORF]5), displaying the amino acid activation module illustrated by the aminoacyl adenylation, thiolation, and condensation domains characteristic of a nonribosomal peptide synthetase (NRPS), and showing a comparison of conserved sequences in adenylation (A) condensation (C) thiolation (T), and reductase (R) domains (Marahiel et al. 1997) of different NRPS from several microorganisms. Conserved amino acids are indicated with bold letters; lack of the domain is denoted as np. Accession number for ORF 5 gene is DQ532442. \% Identity $=$ percentage of deduced protein from ORF5 of Pseudomonas syringae pv. syringae UMAF0158 with the NRPS gene from other bacteria; $P$. syringae pv. syringae B728a (Psyr 5011), P. syringae pv. tomato DC3000 (PSPTO 5457), P. fluorescens PfO-1 (Pflu 3964), Xanthomonas campestris pv. campestris ATCC33913 (XCC3867), Bradyrhizobium japonicum USDA 110 (Blr 2108), Escherichia coli CFT073 (C2459), Streptomyces avermitilis MA 4680 (SAV 603 ), and Bacillus cereus ATCC14579 (BC0423). Consensus sequences are outlined with boxes. 
virulence, syringomycin and syringopeptin production, and putative NRPS expression in P. syringae pv. syringae B301D (Lu et al. 2005; Raaijmakers et al. 2006; Wang et al. 2006). It is remarkable to note the overproduction of lipodepsipeptides by several defective mutants in mangotoxin production, mainly affected in $g a c \mathrm{~A} / g a c \mathrm{~S}$ genes. This fact could suggest a possible coordinated regulation of the production of both toxins, which present different production patterns, so that syringomycins are produced preferentially in rich media, in contrast with mangotoxin and other antimetabolite toxins, which are produced in minimal medium.

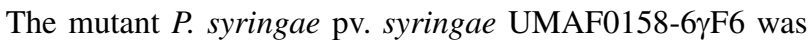
selected for further studies due to the similarity of the gene disrupted by the miniTn $5 \mathrm{~km} 2$ insertion with an NRPS, a key enzyme involved in the production of different antibiotics and phytotoxins (Finking and Marahiel 2004). To study the role of the disrupted NRPS gene, a chromosomal fragment of $11.1 \mathrm{~kb}$ of the wild-type $P$. syringae pv. syringae UMAF0158, cloned into the plasmid pCG2-6, was recovered; which restored the mangotoxin production in the defective mutant (Table 3). The sequence of the 11.1-kb DNA insert revealed the presence of six complete ORFs and genes encoding rRNA (Fig. 1). The ORFs are located close to each other on the same DNA strand and ORFs 3 to 6 could constitute an operon because they are

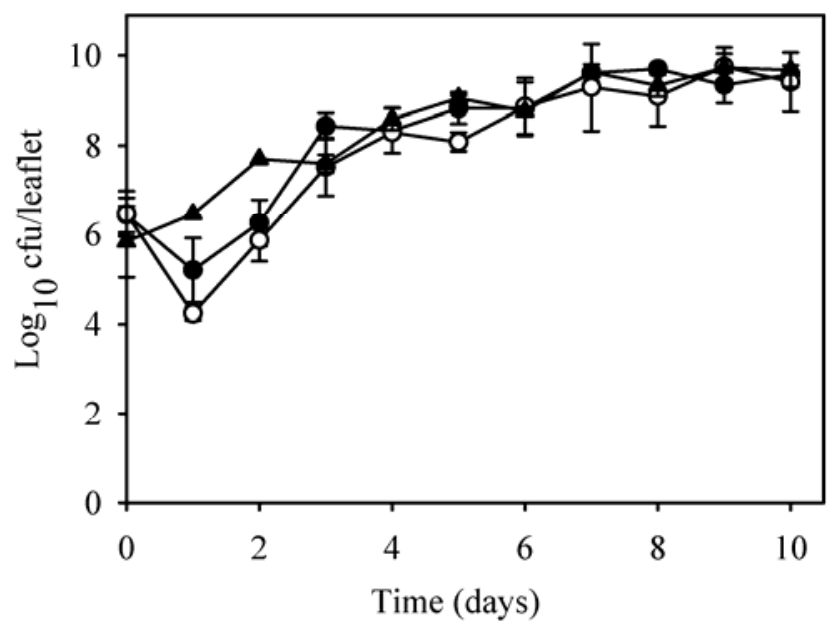

Fig. 3. Time course of bacterial growth in tomato leaflets maintained in vitro and inoculated with mangotoxin-producing and nonproducing strains: the wild-type strain Pseudomonas syringae pv. syringae UMAF0158 (@); $P$. syringae pv. syringae UMAF0158-6 $\gamma \mathrm{F} 6$, a mini $\mathrm{Tn} 5 \mathrm{~km} 2$ mutant defective in mangotoxin production $(\bigcirc)$; and $P$. syringae pv. syringae UMAF2-6A, a derivative strain from $P$. syringae pv. syringae UMAF0158-6 $\gamma \mathrm{F} 6$ harboring pCG2-6 and showing mangotoxin production restored $(\boldsymbol{\Delta})$. Data points are the means of four experiments, and error bars indicate the standard deviations.

Fig. 4. Symptom development on tomato leaflets inoculated with mangotoxin-producing and nonproducing Pseudomonas syringae pv. syringae strains. The assayed strains were the wild-type $P$. syringae pv. syringae UMAF0158 (O); P. syringae pv. syringae UMAF0158-6 $\gamma \mathrm{F} 6$, a mini Tn $5 \mathrm{~km} 2$ mutant defective in mangotoxin production $(O)$; and $P$. syringae pv. syringae UMAF2-6A, a derived strain from $P$. syringae pv. syringae UMAF0158-6 $\gamma \mathrm{F} 6$ by complementation with the plasmid pCG2-6 and showing mangotoxin production restored $(\boldsymbol{\Delta})$. A, Development of the necrotic symptoms was followed during 10 days after inoculation and the cumulative number of inoculation points showing a surrounding necrotic area larger than $2 \mathrm{~mm}$ in diameter was recorded every day after inoculation from a total of 120 inoculated points with every strain (30 inoculation points $\times 4$ experiments). B, Representative symptoms on tomato leaflets at 5 and 10 days after inoculation. located between two putative promoters. The disrupted gene in

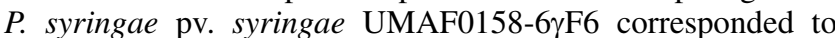
ORF5, with the insertion of the miniTn5 $\mathrm{Km} 2$ at nucleotide 3,014 of this ORF (Fig. 1). This gene was named mgoA, and showed a very high identity to an NRPS, the system involved in synthesis of antibiotic peptides via the nonribosomal thiotemplate mechanism of biosynthesis (Finking and Marahiel

A
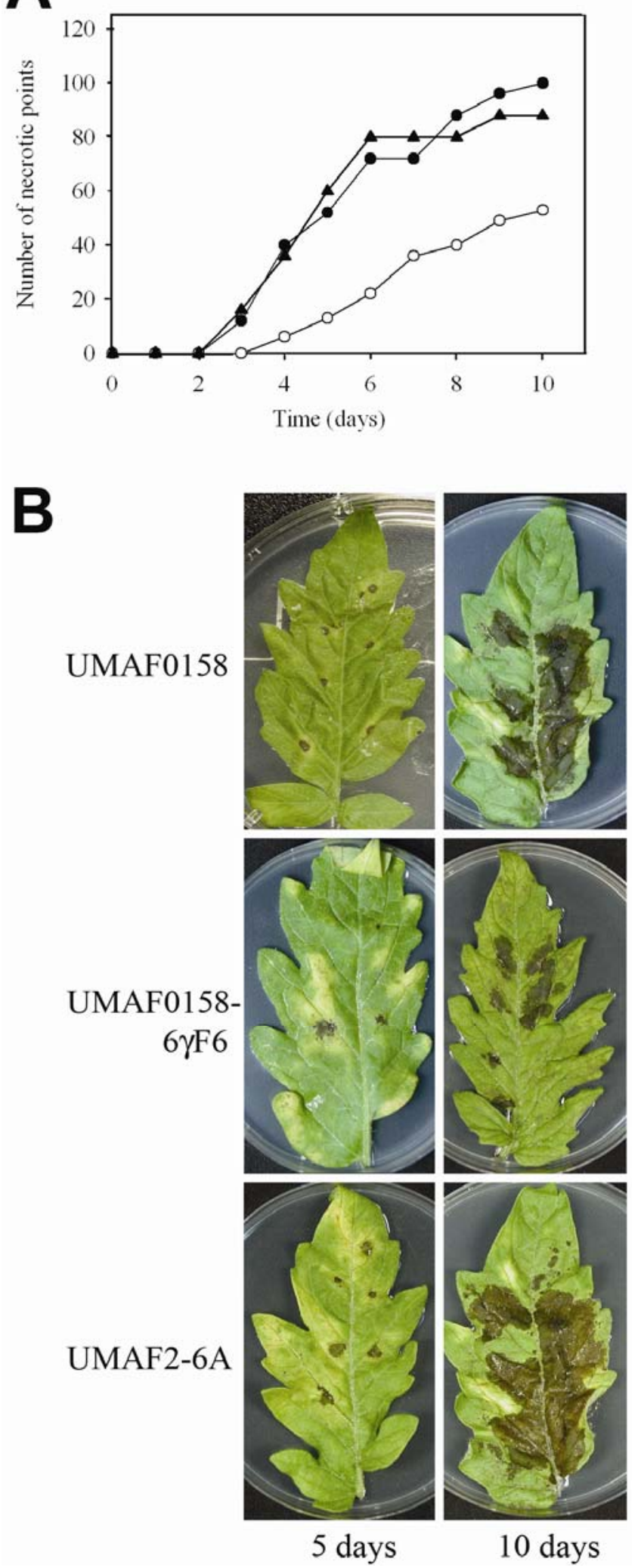

Vol. 20, No. 5, 2007 / 505 
2004). Several NRPS gene clusters have been described for biosynthesis of syringomycin, syringopeptin, or syringolin by P. syringae strains (Amrein et al. 2004; Guenzi et al. 1998; Scholz-Schroeder et al. 2001, 2003).

Analysis of the predicted amino acid sequence from MgoA indicated that it contains only one amino acid activation module typical of a functional NRPS, and it is composed of 14 conserved domains, including aminoacyl adenylation, condensation, thiolation, and additional reduction domains, with a remarkable identity level to other bacterial NRPS, proportional to the phylogenetic distance between them (Fig. 2). The aminoacyl adenylation domains, found at the N-terminal end, seem to be responsible for recognizing and adenylating an amino acid substrate via ATP hydrolysis (Challis et al. 2000; Marahiel et al. 1997). The unstable adenylate then is covalently bound to the thiolation domain of the PCP region, located at the $\mathrm{C}$-terminal portion of the amino acid activation module, in a thioester linkage via a 4'phosphopantheine cofactor to the conserved serine located within the conserved thioester-binding motif LGGHS(T) of this domain (Conti et al. 1997; Fernández-Moreno et al. 1992, Gocht and Marahiel 1994; Schlumbohm et al. 1991; Stein and Vater 1996). In this thiolation domain, the most relevant differences in the amino acid sequence between the putative NRPS deduced from ORF5 of $P$. syringae pv. syringae UMAF0158 and its homologous putative NRPS from $P$. syringae pv. syringae B728a and $P$. syringae pv. tomato DC3000 were observed; therefore, the initial four amino acids of this domain of $P$. syringae pv. syringae UMAF0158 were different from those $P$. syringae strains and similar to those of E. coli CFT073 (Fig. 2). The condensation domains are conventionally fused to the amino terminal end of modules accepting acyl groups from the preceding module, and they are absent in modules activating the first acyl constituent to be incorporated (Konz and Marahiel 1999) although, in the predicted MgoA protein, it was located around the middle of the protein. The condensation domain recently was demonstrated to be necessary for peptide bond formation (De Crécy-Lagard et al. 1995; Stachelhaus et al. 1998). Three potential reductase domains also have been identified at the carboxy terminal end of the predicted ORF5 protein, containing an NADP $(\mathrm{H})$-binding site $\mathrm{R} 1$, characteristic of a diverse group of reductive enzymes (Pospiech et al. 1996; Suvarna et al. 1998). The $\mathrm{R}$ domains terminate many NRPS genes, and they are proposed to cleave the covalent protein-small molecule thioester bonds to release aldehides, which undergo a variety of metabolic fates (Dworkin 1996).

We suggest that an NRPS system encoded in the mgoA gene and described in this article could be involved in the biosynthesis of mangotoxin by introducing only one predicted amino acid (Ile, Leu, Val, Abu, or Iva) to a previous amino acid or oligopeptide, in a way similar to that described for other compounds (Amrein et al. 2004; Byford et al. 1997; Rausch et a. 2005). Mangotoxin structure remains unknown; however, preliminary characterization showed that it is a very small molecule with chromatographical and biochemical characteristics similar to other well-known antimetabolite toxins produced by $P$. syringae, such as tabtoxin and phaseolotoxin, which are di- and tripeptide (Arrebola et al. 2003). Therefore, the precursor molecule for mangotoxin would be an individual amino acid or a short oligopeptide. Similarly, NRPS systems has been described in Pseudomonas spp. and involved in the biosynthesis of small oligopeptides with antimicrobial properties, such as syringolin (Amrein et al. 2004) and ACV-oligopeptide (Byford et al. 1997). The deduced NRPS from mgoA of $P$. syringae pv. syringae UMAF0158 showed a high identity to different NRPS genes (Fig. 2), especially from Pseudomonas spp. and, in particular, from $P$. syringae strains, such as $P$. syringae pv. syringae B728a (Psyr 5011), P. syringae pv. tomato DC3000 (PSPTO 5457), and $P$. syringae pv. phaseolicola 1448A (PSPPH 5090). However, in spite of the fact that $P$. syringae pv. syringae B728a has a putative NRPS gene (Psyr5011) embedded in a cluster highly similar to the chromosomal DNA cloned into the plasmid pCG2-6, P. syringae pv. syringae B728a fails to produce mangotoxin. Whether or not the lack of mangotoxin production by $P$. syringae pv. syringae $\mathrm{B} 728 \mathrm{a}$ could be related to differences in the specificity of the NRPS or a lack of functionality ( $95 \%$ similarity to $m g o \mathrm{~A}$ ) remains to be investigated; however, when $P$. syringae pv. syringae $\mathrm{B} 728$ a was transformed with pCG2-6, it remained without produce mangotoxin (data not shown).

However, this putative NRPS (MgoA) is not the unique protein responsible for the production of mangotoxin, and it could be involved in initial biosynthetic steps of mangotoxin or another oligopeptide produced by $P$. syringae. However, it is clear that the mgoA gene is not involved in the lipodepsinonapeptide biosynthesis (Table 2). On the other hand, we also obtained evidences of other genes, not present in $P$. syringae pv. syringae B728a (genes disrupted in mutants $4 \beta \mathrm{A} 2$ and $5 \alpha \mathrm{C5}$ ) (Table 2) which also could be involved in specific processes for mangotoxin production, suggesting specific reactions for mangotoxin production encoded out of the predicted operon containing the putative NRPS of $m g o A$.

The role of NRPS in the production of bacterial phytotoxins involved in virulence or plant pathogenesis also has been reported from other plant-pathogenic bacteria, such as Xanthomonas albilineans (Royer et al. 2004) or Streptomyces acidiscabies (Healy et al. 2000). In this sense, we established a clear relationship between the activity of $m g o A$ and the virulence of $P$. syringae pv. syringae UMAF0158 on tomato leaflets. Artificial inoculation experiments showed that the mangotoxin-defective mutant $P$. syringae pv. syringae UMAF0158-6 $\gamma \mathrm{F} 6$ and the mangotoxin-producer $P$. syringae pv. syringae UMAF0158 and $P$. syringae pv. syringae UMAF2-6A strains grew at similar rates and reached similar population densities in inoculated tomato leaflets (Fig. 3). Similar results have been described for a $P$. syringae pv. tomato DC3000 avrE1 mutant that is reduced in its ability to produce lesions but not in its ability to grow in host tomato leaves (Badel et al. 2006). However, the disease symptoms caused by the mangotoxin-defective mutant strain $P$. syringae pv. syringae UMAF0158-6 $\gamma \mathrm{F} 6$ clearly were less severe than those produced by the wild-type and the complemented mangotoxin-producing strains. These findings are similar to those previously demonstrated for other toxins, such

Table 4. Effective dose of mangotoxin-producing and nonproducing Pseudomonas syringae pv. syringae strains to induce necrotic symptoms in 50\% of the inoculations on tomato leaflets $\left(\mathrm{ED}_{50}\right)$

\begin{tabular}{|c|c|c|c|}
\hline Strains & $\begin{array}{c}\text { Mangotoxin } \\
\text { production }\end{array}$ & Characteristics & $\mathbf{E D}_{50}$ \\
\hline \multicolumn{4}{|c|}{ P. syringae pv. syringae } \\
\hline UMAF0158 & + & Wild type, produces mangotoxin & $1.8 \times 10^{6}$ \\
\hline 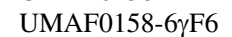 & - & Contains a mini $T n 5 \mathrm{~km} 2$ insertion in a putative nonribosomal peptide synthetase & $5.3 \times 10^{7}$ \\
\hline UMAF2-6A & + & UMAF0158-6 $\gamma \mathrm{F} 6$ complemented with the plasmid pCG2-6 & $8.0 \times 10^{5}$ \\
\hline UMAF0158-4ßE6 & + & mini $T n 5 \mathrm{~km} 2$ mutant used as control & $1.9 \times 10^{6}$ \\
\hline
\end{tabular}


as coronatine (Mittal and Davis 1995) and other antimetabolite toxins from P. syringae (Engst and Shaw 1992; Peet et al. 1986). In inoculated tomato leaflets, the wild-type and complemented strains caused necrotic symptoms which began to be apparent on the third day post inoculation, and reached approximately $80 \%$ severely affected inoculation points on the tenth day post inoculation. In contrast, the mangotoxin-defective $P$. syringae pv. syringae UMAF0158-6 $\gamma \mathrm{F} 6$ produced tissue necrosis in a lower number of inoculation sites (approximately $40 \%$ inoculation points affected on the tenth day post inoculation) and, in this case, the symptoms began to be apparent on the fourth day post inoculation. Thus, the mangotoxin-defective mutant displays a clear delay in the initiation and development of the necrotic symptoms, in comparison with the mangotoxin-producing strains (Fig. 4). However, necrotic symptoms are still present at lower levels in mangotoxin-defective strains, mainly due to the production of other compounds related to the virulence (such as lipodepsipeptidic toxins) not affected by the Tn 5 insertion in those mutants. The role of the putative NRPS-encoding gene in the production of mangotoxin and its involvement in the symptoms development also was revealed by the $\mathrm{ED}_{50}$ experiments. The median effective dose $\left(E D_{50}\right)$ is a value directly related to the virulence of the inoculated strains (Cazorla et al. 1998; Ercolani 1984). The $\mathrm{ED}_{50}$ determined after artificial inoculations on tomato leaflets showed clearly higher values for $P$. syringae pv. syringae UMAF0158-6 $\gamma$ F6 than for $P$. syringae pv. syringae UMAF0158 and $P$. syringae pv. syringae UMAF2-6A, revealing a higher virulence for the mangotoxin-producing strains than for the mutant with the disrupted NRPS gene, defective in mangotoxin production (Table 4).

The putative NRPS gene $(m g o \mathrm{~A})$ that we have identified in this study is the first gene described for $P$. syringae pv. syringae which is directly involved in the biosynthesis of mangotoxin, and also is associated with virulence in the mangotoxinproducing strains.

\section{MATERIALS AND METHODS}

Bacterial strains, plasmids, and mutagenesis.

The bacterial strains and plasmids used in this study are listed in Table 1. P. syringae pv. syringae strains were grown in King's medium B (KMB) at $22^{\circ} \mathrm{C}$, and E. coli strains were grown in Luria-Bertani medium (LB) at $37^{\circ} \mathrm{C}$. Transposon mutagenesis of $P$. syringae pv. syringae UMAF0158 was carried out by mating experiments on nitrocellulose membrane $(0.22 \mu \mathrm{m})$ onto $\mathrm{LB}$ agar at $27^{\circ} \mathrm{C}$ for $2 \mathrm{~h}$ using E. coli $\mathrm{S} 17 \lambda$ pir containing the Tn5-derived minitransposon pUT-mini Tn $5 \mathrm{~km} 2$ as donor strain (de Lorenzo and Timmis 1994). Derivative strains were isolated after $48 \mathrm{~h}$ at $22^{\circ} \mathrm{C}$ on $\mathrm{KMB}$ amended with kanamycin $(30 \mu \mathrm{g} / \mathrm{ml})$ and nitrofurantoin $(100 \mu \mathrm{g} / \mathrm{ml})$ as selective agents.

The growth of $P$. syringae pv. syringae UMAF0158 derivative strains were characterized on Pseudomonas minimal medium (PMS) broth at $22^{\circ} \mathrm{C}$. Bacterial counts were determined every day on $\mathrm{KMB}$ at $22^{\circ} \mathrm{C}$ after $48 \mathrm{~h}$.

\section{Detection of $P$. syringae pv. syringae toxins.}

The lipodepsipeptidic toxins produced by $P$. syringae pv. syringae strains were demonstrated by the growth inhibition bioassay on potato-dextrose agar (PDA) using Geotrichum candidum (Gross and DeVay 1977) and Rhodotorula pilimanae (Iacobellis et al. 1992) as indicator strains.

The antimetabolite toxin production was assayed by the indicator technique previously described (Gasson 1980) with minor modifications (Arrebola et al. 2003), which relies on the inhibition of growth of E. coli CECT 831 on PMS (Gasson
1980). Briefly, a double layer of indicator microorganism was made using strain CECT831 of E. coli. After solidification, strains of $P$. syringae pv. syringae to be tested were stabbed and plates were incubated at $22^{\circ} \mathrm{C}$ for $24 \mathrm{~h}$ and $37^{\circ} \mathrm{C}$ for an additional 24-h period. To assess the biochemical step that is the putative target of the toxin, the same plate bioassay was carried out, but adding to the double layer $100 \mu \mathrm{l}$ of a 6-mM solution of $\mathrm{N}$-acetyl-ornithine or L-ornithine (Arrebola et al. 2003). Testing of toxic filtrates from $P$. syringae pv. syringae strains was done by growing bacteria in liquid PMS for $48 \mathrm{~h}$ at $22^{\circ} \mathrm{C}$; the supernatants then were filtered through $0.22-\mu \mathrm{m}$ nitrocellulose membranes (Arrebola et al. 2003) and tested by $E$. coli growth inhibition bioassays as described above.

\section{OAT enzymatic assay.}

OAT activity experiments were carried out using crude protein extracts from tomato leaves (Arrebola et al. 2003). In the standard assay, $25 \mu \mathrm{l}$ of $6 \mathrm{mM} \mathrm{N}$-acetyl-L-ornithine and $25 \mu \mathrm{l}$ of $6 \mathrm{mM}$ L-glutamine were mixed with $50 \mu \mathrm{l}$ of crude protein extract of tomato leaves, together with $25 \mu \mathrm{l}$ of the culture filtrate to be tested. After $1 \mathrm{~h}$ of incubation at $37^{\circ} \mathrm{C}$, the reaction was stopped by adding three volumes of ninhydrin reagent and heated at $100^{\circ} \mathrm{C}$ for $1.5 \mathrm{~min}$. Two volumes of $0.7 \mathrm{M} \mathrm{NaOH}$ then were added and the absorbance at $470 \mathrm{~nm}$ recorded after $20 \mathrm{~min}$ of incubation at room temperature (Arrebola et al. 2003). The amount of ornithine was determined colorimetrically by using a standard curve prepared for this purpose as reference (Dénes 1970; Vogel and McLellan 1970). A 0.2-mM solution of p-chloromercuribenzoic acid, a chemical inhibitor of OAT (Dénes 1970), and sterile liquid PMS were used as controls.

\section{DNA manipulation and sequencing.}

DNA isolation was performed by a standard protocol (Sambrook and Russell 2001). Plasmid mini-preps were done using the Qiaprep spin miniprep kit (Qiagen GmbH, Düsseldorf, Germany). For sequence analysis of the regions flanking the miniTn5 insertions, the primers "KS" (5'TCGAGGTCG ACGGTATC3") and "Tn5K2-P4" (5'GGCAGAGCATTACG CTGACT3') were used. For the construction of a genomic library of the wild-type $P$. syringae pv. syringae UMAF0158, isolation of genomic DNA was carried out using the Puregene commercial kit (Gentra Systems, Minneapolis, MN, U.S.A.). The genomic library was constructed using $\lambda$ BlueSTAR Vector System (Novagen, Darmstadt, Germany), and genomic DNA of $P$. syringae pv. syringae UMAF0158 digested with Sau3A, following the manufacturer's recommendations. Automated DNA sequencing of genomic clones was carried out by Newbiotechnic S.A. (Sevilla, Spain).

Isolation and characterization of wild-type genomic clones.

To obtain genomic clones containing the Tn5 insertions, Southern blot analysis was performed. PstI-digested genomic DNA from selected mutants was hybridized with a Tn5 fragment as probe to determine the sizes of fragments containing that Tn5 element. Genomic DNA fragments containing the appropriate size range were ligated into pBluescript II $\mathrm{KS}(+)$ and transformed into $E$. coli DH5 $\alpha$. After plating the transformants onto selective media, kanamycin-resistant colonies were isolated and the transposon-containing inserts were purified. This DNA was used as a probe to screen the wild-type $P$. syringae pv. syringae UMAF0158 genomic DNA phage library. To obtain phagemid clones containing a chromosomal fragment harboring genes of mangotoxin, a 256-bp fragment from mangotoxindefective mutant $P$. syringae pv. syringae UMAF0158-6 $\gamma \mathrm{F} 6$, flanking the Tn5 insertion, was used as a probe in phage library screening on the phage plaques formed on the lysogenic 
E. coli ER1647 strain. Of 3,000 plaques screened, eight phagemids hybridized to the probe.

Phage infections on the nonlysogenic E. coli BM25.8 were performed in order to obtain independent plasmids, and one of them, the plasmid pCG2-6, was selected for further studies.

\section{Bioinformatics.}

Database searches were performed with the BLAST 2.0 service of the National Center for Biotechnology Information (Bethesda, MD, U.S.A.). Amino acid sequences were aligned with ClustalW service of the EMBL European Bioinformatics Institute (Cambridge, U.K.). For mapping the chromosomal fragment cloned in plasmid pCG2-6, a comparison analysis with $P$. syringae pv. syringae $\mathrm{B} 728$ a genome was carried out, and it was confirmed by using Artemis software (Sanger Institute, Cambridge, U.K.). The putative promoter site prediction was performed analyzing the sequences out of the ORF with two bioinformatic applications, BPROM software (Softberry Inc., Mount Kisco, NY, U.S.A.) and NNPP 2.2. software (Berkeley Drosophila Genome Project-BDGP, Berkeley, CA, U.S.A.).

Analysis of the predicted substrate-binding region and substrate amino acid for ORF5 was performed with the NRPS predictor software (Rausch et al. 2005).

\section{Plant material, bacterial inoculation, and disease symptom evaluation.}

Inoculation experiments were performed using tomato plants (Lycopersicon esculentum Mill.) cv. Hellfrucht Frühstamm. Plants were grown in greenhouse under natural light. Prior to inoculation, tomato leaflets from 6- to 8-week-old plants were detached, disinfected in $0.1 \%$ (wt/vol) $\mathrm{HgCl}_{2}$ solution, and placed in petri dishes with their petioles immersed in Murashige and Skoog (MS) agar medium (Sigma-Aldrich, St. Louis) (Pérez-García et al. 1995). Inoculations were conducted with the $P$. syringae pv. syringae strains UMAF0158, UMAF0158$6 \gamma$ F6, and UMAF2-6A, which produces levels of lipodepsipeptidic toxins similar to the wild-type strain (Table 1). Detached leaflets were inoculated by placing six $10-\mu$ droplets of approximately $10^{8} \mathrm{CFU} / \mathrm{ml}$ bacterial suspensions on the principal lateral veins. Then, inoculations were performed by piercing through the droplets with an entomological pin. The leaflets were maintained at $22^{\circ} \mathrm{C}$ under a 16 -h photoperiod. Five tomato leaflets were used to evaluate symptoms for each assayed strain. Leaflets treated with sterile water and maintained in MS medium were included in all experiments as a control. All experiments were repeated four times.

Appearance of necrotic areas at inoculation points were recorded daily over a 10-day period by visual analysis. Necrotic area surrounding the inoculation point larger than $2 \mathrm{~mm}$ was considered positive. In parallel, two inoculated leaflets were used every day to determine the bacterial densities. Tomato leaflets were homogenized in sterile phosphate-buffered saline. Then, bacterial populations were determined by serial dilutions on plates of KMB after incubation at $27^{\circ} \mathrm{C}$ during $48 \mathrm{~h}$.

To estimate the $\mathrm{ED}_{50}$ of $P$. syringae pv. syringae strains, inoculation with bacterial suspensions of different cell densities (approximately $10^{2}$ to $10^{7} \mathrm{CFU}$ per inoculation point) were carried out as described below. Suspensions of each strain at different bacterial concentrations were prepared, and six leaflets (six inoculation points per leaflet) were inoculated with each bacterial suspension. The number of inoculated points showing necrotic symptoms was recorded after 10 days. Each experiment was repeated four times. Then, a dose-response curve was produced by plotting the bacterial dose ( $\log _{10}$-transformed) against a Weibull transformation of the proportion of diseased inoculation points $\left(\log _{10}\left[-\log _{e}(1-R)\right]\right)$. A straight line was fitted to the data points that were not equal to a 0 or $100 \%$ response and the value of dose corresponding to $50 \%$ of inoculated points showing necrotic symptoms $\left(\mathrm{ED}_{50}\right)$ was obtained (Shortley and Wilkins 1965).

\section{ACKNOWLEDGMENTS}

This work was partially supported by grants from the Junta de Andalucía (AGR-169) and from Plan Nacional de I+D del Ministerio de Educación y Ciencia, PETRI PTR1995-0723-OP, AGL2004-06056-C02-01, and AGL2004-07028-CO3-02. We acknowledge J. A. Torés for helpful suggestions and work facilities at Estación Experimental "La Mayora" (CSIC, Málaga, Spain), J. Murillo for critical review and suggestions about this manuscript, and M. A. Vázquez for her assistance in some experiments.

\section{LITERATURE CITED}

Amrein, H., Makart, S., Granado, J., Shakya, R., Schneider-Pokorny, J., and Dudler, R. 2004. Functional analysis of genes involved in the synthesis of syringolin A by Pseudomonas syringae pv. syringae B301D-R. Mol. Plant-Microbe Interact. 17:90-97.

Arrebola, E., Cazorla, F. M., Durán, V. E., Rivera, E., Olea, F., Codina, J. C., Pérez-García, A., and de Vicente, A. 2003. Mangotoxin: A novel antimetabolite toxin produced by Pseudomonas syringae inhibiting ornithine/arginine biosynthesis. Physiol. Mol. Plant Pathol. 63:117-127.

Bachmann, A. S., Matile, P., and Slusarenko, A. J. 1998. Inhibition of ornithine decarboxylase activity by phaseolotoxin: Implications for symptom production in halo blight of French bean. Physiol. Mol. Plant Pathol. 53:287-299.

Backman, P. A., and DeVay, J. E. 1971. Studies on the mode of action and biogenesis of the phytotoxin syringomycin. Physiol. Plant Pathol. $1: 215-234$.

Badel, J. L., Shimizu, R., Oh, H. S., and Collmer, A. 2006. A Pseudomonas syringae pv. tomato avrE1/hopM1 mutant is severely reduced in growth and lesion formation in tomato. Mol. Plant-Microbe Interact. 19:99-111.

Bender, C., Alarcón-Chaidez, F., and Gross, D. C. 1999. Pseudomonas syringae phytotoxins: Mode of action, regulation, and biosynthesis by peptide and polyketide synthetases. Microbiol. Mol. Biol. Rev. 63:266-292.

Byford, M. F., Baldwin, J. E., Shian, C. Y., and Schofield, C. J. 1997. The mechanism of ACV synthetase. Chem. Rev. 97:2631-2650.

Cazorla, F. M., Torés, J. A., Olalla, L., Pérez-García, A., Farré, J. M., and de Vicente, A. 1998. Bacterial apical necrosis of mango in southern Spain: A disease caused by Pseudomonas syringae pv. syringae. Phytopathology 88:614-620.

Cazorla, F. M., Arrebola, E., del Moral, E., Rivera, E., Olea, F., PérezGarcía, A., and de Vicente, A. 2003. An antimetabolite toxin (mangotoxin) is produced by Pseudomonas syringae pv. syringae isolated from mango. Pages 175-183 in: Pseudomonas syringae and Related Pathogens: Biology and Genetic. N. S. Iacobellis, Collmer, A., Hutcheson, S.W., Mansfield, J. W., Morris, C. E., Murillo J., Schaad, N. W., Stead, D.E., Surico, G., and Ullrich, M, eds. Kluwer Academic Publishers, Dordrecht, The Netherlands.

Challis, G. L., Ravel, J., and Townsend, C. A. 2000. Predictive, structure based model of amino acid recognition by nonribosomal peptide synthetase adenylation domains. Chem. Biol. 7:211-224.

Conti, E., Stachelhaus, T., Marahiel, M. A., and Brick, P. 1997. Structural basis for the activation of phenylalanine in the non-ribosomal biosynthesis of gramicidin S. EMBO (Eur. Mol. Biol. Organ.) J. 16:4174-4183.

De Crécy-Lagard, V., Marliére, P., and Saurin, W. 1995. Multienzymatic nonribosomal peptide biosynthesis: Identification of the functional domains catalyzing peptide elongation and epimerisation. C. R. Acad. Sci. Paris 318:927-936.

De Lorenzo, V., and Timmis, K. N. 1994. Analysis and construction of stable phenotypes in gram-negative bacteria with Tn5 and Tn10-derived mini-transposons. Methods Enzymol. 235:386-405.

Dénes, G. 1970. Ornithine acetyltransferase (Chlamydomonas reinhardti). Methods Enzymol. 17:273-277.

Durbin, R. D. 1991. Bacterial phytotoxins: Mechanism of action. Experientia 47:776-783

Dworkin, M. 1996. Recent advances in the social and developmental biology of the myxobacteria. Microbiol. Rev. 60:70-102.

Engst, K., and Shaw, P. D. 1992. Identification of a lysA-like gene required for tabtoxin biosynthesis and pathogenicity in Pseudomonas syringae pv. tabaci strain PTBR2.024. Mol. Plant-Microbe Interact. 5:322-329.

Ercolani, G. 1984. Infectivity titration with bacterial plant pathogens. Annu. Rev. Phytopathol. 22:35-52. 
Fernández-Moreno, M. A., Martínez, E., Boto, L., Hopwood, D. A., and Malpartida, F. 1992. Nucleotide sequence and deduced functions of a set of cotranscribed genes of Streptomyces coleicolor A3(2) including the polyketide synthase for the antibiotic actinorhodin. J. Biol. Chem. 267:19278-19290.

Finking, R., and Marahiel, M. A. 2004. Biosynthesis of nonribosomal peptides. Annu. Rev. Microbiol. 58:453-488.

Gasson, M. J. 1980. Indicator technique for antimetabolic toxin production by phytopathogenic species of Pseudomonas. Appl. Environ. Microbiol. 39:25-29.

Gocht, M., and Marahiel, M. A. 1994. Analysis of core sequences in the D-phe activating domain of the multifunctional peptide synthetase TycA by site-directed mutagenesis. J. Bacteriol. 176:2654-2662.

Grgurina, I., and Benincasa, M. 1994. Evidence of the nonribosomal biosynthetic mechanism in the formation of syringomycin and syringopeptin, bioactive lipodepsipeptides of the phytopathogenic bacterium Pseudomonas syringae pv. syringae. Ital. Biochem. Soc. Trans. 5:143.

Gross, D. C. 1991. Molecular and genetic analysis of toxin production by pathovars of Pseudomonas syringae. Annu. Rev. Phytopathol. 29:247278.

Gross, D. G., and De Vay, J. E. 1977. Production and purification of syringomycin, a phytotoxin produced by Pseudomonas syringae. Physiol. Plant Pathol. 11:13-28.

Guenzi, E., Galli, G., Grgurina, I., Gross, D. C., and Grandi, G. 1998. Characterization of the syringomycin synthetase gene cluster. A link between prokaryotic and eukaryotic peptide synthetases. J. Biol. Chem. 273:32857-32863.

Hanahan, D. 1985. Techniques for transformation of E. coli. Pages 109 135 in: DNA Cloning: A Practical Approach. D. M. Glover, ed. IRL Press, Oxford, U.K.

Healy, F. G., Wach, M., Krasnoff, S. B., Gibson, D. M., and Loria, R. 2000. The $t x t A B$ genes of the plant pathogen Streptomyces acidiscabies encode a peptide synthetase required for phytotoxin thaxtomin A production and pathogenicity. Mol. Microbiol. 38:794-804.

Heeb, S., and Hass, D. 2001. Regulatory roles of the GacS/GacA twocomponent system in plant-associated and other gram-negative bacteria. Mol. Plant-Microbe Interact. 14:1351-1363.

Hernández-Guzmán, G., and Alvarez-Morales, A. 2001. Isolation and characterization of the gene coding for the amidinotransferase involved in the biosynthesis of phaseolotoxin in Pseudomonas syringae pv. phaseolicola. Mol. Plant-Microbe Interact. 14:545-554.

Hirano, S. S., and Upper, C. D. 1990. Population biology and epidemiology of Pseudomonas syringae. Annu. Rev. Phytopathol. 28:155-177.

Iacobellis, N. S., Lavermicocca, P., Grgurina, I., Simmaco, M., and Ballio, A. 1992. Phytotoxic properties of Pseudomonas syringae pv. syringae toxins. Physiol. Mol. Plant Pathol. 40:107-116.

Konz, D., and Marahiel, M. A. 1999. How do peptide synthetases generate structural diversity? Chem. Biol. 6:39-48.

Lu, S. E., Scholz-Schroeder, B. K., and Gross, D. C. 2002. Characterization of the salA, $s y r F$, and $s y r G$ regulatory genes located at the right border of the syringomycin gene cluster of Pseudomonas syringae pv. syringae. Mol. Plant-Microbe Interact. 15:43-53.

Lu, S. E., Wang, N., Wang, J., Chen, J., and Gross, D. C. 2005. Oligonucleotide microarray analysis of the SalA regulon controlling phytotoxin production by Pseudomonas syringae pv. syringae. Mol. Plant-Microbe Interact. 18:324-333.

Marahiel, M. A. 1997. Protein templates for the biosynthesis of peptide antibiotics. Chem. Biol. 4:561-567.

Marahiel, M. A., Stachelhaus, T., and Mootz, H. D. 1997. Modular peptide synthetases involved in nonribosomal peptide synthesis. Chem. Rev. 97:2651-2673.

Märkisch, U., and Reuter, G. 1990. Biosynthesis of homoarginine and ornithine as precursors of the phytoeffector phaseolotoxin by the amidinotransfer from arginine to lysine catalyzed by an amidinotransferase in Pseudomonas syringae pv. phaseolicola. J. Basic Microbiol. 30:425-433.

Mitchell, R. E. 1984. The relevance of non-host toxins in the expression of virulence by pathogens. Annu. Rev. Phytopathol. 22:215-245.

Mitchell, R. E. 1991. Implications of toxins in the ecology and evolution of plant pathogenic microorganisms: Bacteria. Experientia 47:791-803.

Mittal, S., and Davis, K. R. 1995. Role of the phytotoxin coronatine in the infection of Arabidopsis thaliana by Pseudomonas syringae pv. tomato. Mol. Plant-Microbe Interact. 8:165-171.

Patil, S. S., Tam, L. Q., and Sakai, W. S. 1972. Mode of action of the toxin from Pseudomonas phaseolicola. I. Toxin specificity, chlorosis and ornithine accumulation. Plant Physiol. 49:803-807.

Peet, R. C., Lindaren, P. B., Willis, D. K., and Panopoulos, N. J. 1986 Identification and cloning of genes involved in phaseolotoxin production by Pseudomonas syringae pv. phaseolicola. J. Bacteriol. 166:1096-1105.

Pérez-García, A., Cánovas, F. M., Gallardo, F., Hirel, B., and de Vicente, A. 1995. Differential expression of glutamine synthetase isoforms in tomato detached leaflets infected with Pseudomonas syringae pv. tomato. Mol. Plant-Microbe Interact. 8:96-103.

Pospiech, A., Bietenhader, J., and Schupp, T. 1996. Two multifunctional peptide synthetases and an $O$-methyltransferase are involved in the biosynthesis of the DNA binding antibiotic and antitumour agent saframycin Mx1 from Myxococcus xanthus. Microbiology 142:741-746.

Raaijmakers, J. M., de Brujin, I., and Kock, M. J. D. 2006. Cyclic lipopeptide production by plant-associated Pseudomonas spp.: Diversity, activity, biosynthesis and regulation. Mol. Plant-Microbe Interact. 19:699. 710

Rausch, C., Weber, T., Kohlbacher, O., Wohlleben, W., and Huson, D. H. 2005. Specificity prediction of adenylation domains in nonribosomal peptide synthetases (NRPS) using transductive support vector machines (TSVM). Nucleic Acid Res. 33:5799-5808.

Roth, P., Hädener, A., and Tamm, C. 1990. Further studies on the biosynthesis of tabtoxin (wildfire toxin): Incorporation of $\left[2,3-{ }^{13} \mathrm{C}_{2}\right]$ pyruvate into the $\beta$-lactam moiety. Helv. Chim. Acta 73:476-482.

Royer, M., Costet, L., Vivien, E., Bes, M., Cousin, A., Damais, A., Pieretti I., Savin, A., Megessier, S., Viard, M., Frutos, R., Gabriel, D. W., and Rott, P. C. 2004. Albicidin pathotoxin produced by Xanthomonas albilineans is encoded by three large PKS and NRPS genes present in a gene cluster also containing several putative modifying, regulatory, and resistance genes. Mol. Plant-Microbe Interact. 17:414-427.

Sambrook, J., and Russell, D. W. 2001. Molecular Cloning: A Laboratory Manual. Cold Spring Harbor Laboratory Press, Cold Spring Harbor, NY, U.S.A

Schlumbohm, W., Stein, T., Ullrich, C., Vater, J., Krause, M., Marahiel, M. A., Kruft, V., and Wittmann-Liebold, B. 1991. An active serine is involved in covalent substrate amino acid binding at each reaction center of gramicidin S synthetase. J. Biol. Chem. 266:23135-23141.

Scholz-Schroeder, B. K., Hutchison, M. L., Grgurina, I., and Gross, D. C. 2001. The contribution of syringopeptin and syringomycin to virulence of Pseudomonas syringae pv. syringae strain B301D on the basis of sypA and syrB1 biosynthesis mutant analysis. Mol. Plant-Microbe Interact. 14:336-348.

Scholz-Schroeder, B. K., Soule, J. D., and Gross, D. C. 2003. The sypA, sypB, and syp $C$ synthetase genes encode twenty-two modules involved in the nonribosomal peptide synthesis of syringopeptin by Pseudomonas syringae pv. syringae strain B301D. Mol. Plant-Microbe Interact. 16:271-280.

Schwarzer, D., Finking, R., and Marahiel, M. A. 2003. Nonribosomal peptides: From genes to products. Nat. Prod. Rep. 20:275-287.

Segre, A., Bachmann, R. C., Ballio, A., Bossa, F., Grgurina, I., Iacobellis, N. S., Marino, G., Pucci, P., Simmaco, M., and Takemoto, J.Y. 1989. The structure of syringomycins A1, E and G. FEBS (Fed. Eur. Biol. Soc.) Lett. 255:27-31.

Shortley, G., and Wilkins, J. R. 1965. Independent-action and birth-dead models in experimental microbiology. Bacteriol. Rev. 29:102-141.

Stachelhaus, T., Mootz, H. D., Bergendahl, V., and Marahiel, M. A. 1998. Peptide bond formation in nonribosomal peptide biosynthesis. Catalytic role of the condensation domain. J. Biol. Chem. 273:22773-22781.

Stein, T., and Vater, J. 1996. Amino acid activation and polymerization at modular multienzymes in nonribosomal peptide biosynthesis. Amino Acids 10:201-227.

Suvarna, K., Seah, L., Bhattacherjee, V., and Bhattacherjee, J. K. 1998. Molecular analysis of the LYS2 gene of Candida albicans: Homology to peptide antibiotic synthetases and the regulation of the alpha-aminoadipate reductase. Curr. Genet. 33:268-275.

Thomas, M. D., Langston-Unkefer, P. J., Uchytil, T. F., and Durbin, R. D. 1983. Inhibition of glutamine synthetase from pea by tabtoxinine- $\beta$-lactam. Plant Physiol. 71:912-915.

Unkefer, C. J., London, R. E., Durbin, R. D., Uchytil, T. F., and LangstonUnkefer, P. J. 1987. The biosynthesis of tabtoxinine-beta-lactam use of specifically C-13-labeled glucose and C-13-NMR-spectroscopy to identify its biosynthetic precursors. J. Biol. Chem. 262:4994-4999.

Vogel, H. J., and McLellan, W. L. 1970. Acetylornithinase (Escherichia coli). Methods Enzymol. 17A:265-269.

Wang, N., Lu, S. E., Wang, J., Chen, Z. J., and Gross, D. C. 2006. The expression of genes encoding lipodepsipeptide phytotoxins by Pseudomonas syringae pv. syringae is coordinated in response to plant signal molecules. Mol. Plant-Microbe Interact. 19:257-269.

Zhang, Y. X., and Patil, S. S. 1997. The phtE locus in the phaseolotoxin gene cluster has ORFs with homologies to genes encoding amino acid transferase, the AraC family of transcriptional factors, and fatty acid desaturases. Mol. Plant-Microbe Interact. 10:947-960. 